\title{
Revelation and Religious Authority in the Sinai Traditions
}

\author{
Benjamin Sommer
}

What, exactly, did the Israelite nation see and hear at Sinai?

This is no merely academic query. The event that transpired at Mount Sinai some three months after the Exodus belongs to the threefold cord that is fundamental to all Jewish existence. Along with the redemption from slavery and the gift of the Land of Israel, the experience at Sinai created the amalgam of religion and ethnicity known as Judaism.

Everyday religious Jews recite the blessing, "Blessed are you, Hashem our God, King of the Universe, who chose us from among all the peoples and gave us his Torah." In Pirkei Avot we learn that "Moses received Torah from Sinai." But what do the verbs "give" and "receive" mean in these contexts? As the authority of the halakhah and the sanctity of the Bible rest upon these words, a thorough analysis of their meanings is in order. ${ }^{1}$ This inquiry is particularly important in our time, as the conclusions of biblical criticism and rationalphilosophical skepticism have made it difficult for modern Jews to believe in the revelation at Sinai, at least in its pure, straightforward, simplistic formulation. Many Jews, including those who are observant, find it difficult to believe that God dictated all the words of the Torah to Moses, who then wrote them down "like a scribe taking dictation."

Moreover, the Pentateuch contains internal inconsistencies and intellectual and ethical difficulties. There are verses in the Torah that command us to kill innocent people from the seven nations and Amalek, including children and babies. It is difficult to believe that these verses express the will of a merciful and just God. The identification of human elements in the Bible 
solves some of these problems but raises others: How is it possible to remain faithful to the Torah yet at the same time analyze it with intellectual objectivity? How can we both love a tradition and emend it? If some of the laws and commandments in the Torah were not written by Moses as dictated directly by God, but are instead the work of human scribes and lawmakers, what authority do they have?

One twentieth-century solution to this problem was to understand revelation as an interactive dialogical process. Proponents of this school of thought include Franz Rosenzweig and Abraham Joshua Heschel, as well as Nahum Glatzer and Louis Jacobs. According to these thinkers, revelation was a reciprocal process to which God and the Jewish people both contributed. To be more precise, the people received a divine message and reacted to it. The Bible is the product of those reactions. This well-known opinion was expressed by Rosenzweig in a letter to Martin Buber: "The primary content of revelation is revelation itself. 'He came down'-this already concludes the revelation; 'He spoke' is the beginning of interpretation, and certainly 'I am.'”3

In his book God in Search of Man, Rabbi Heschel explained:

As a report about revelation the Bible itself is a midrash. ... Judaism is based upon a minimum of revelation and a maximum of interpretation, upon the will of God and upon the understanding of Israel... . There is a partnership of God and Israel in regard to both the world and the Torah: He created the earth and we till the soil; He gave us the text and we refine and complete it. "The Holy One, blessed be He, gave the Torah unto Israel like wheat from which to derive fine flour, or like flax from which to make a garment."

Both these thinkers viewed revelation as an actual event and rejected the idea that the revelation at Sinai was a metaphor or a mythological prototype. Moreover, Heschel, and in my opinion also Rosenzweig, understood this event as authoritative - in other words, as an event in which God gave authoritative instructions to the People of Israel. ${ }^{5}$ Nonetheless, both also raised doubts about the precise nature of the event and argued that it is impossible to know exactly what happened there, or to what extent the specific commandments in the Torah are of divine origin. In their opinion, the text of the Torah is a human reaction to, or interpretation of, an event in which the divine will was expressed by supralinguistic means. Thus, Rosezweig and Heschel encourage us both to accept the Torah as authoritative in the halakhic sense and to question it. 
They challenge us to wonder to what extent are its laws of divine origin? Their writings leave the reader to ponder the nature of the Torah: is it perfect and divine, or human and always tending towards perfection? ${ }^{6}$

\section{Revelation in the Book of Exodus}

These questions are not new. A careful reading of the biblical narrative of the revelation of the Torah at Sinai uncovers hints of these questions in the biblical text itself. These hints raise the possibility that the connection between the divine voice and the text ascribed to Moses is not simple. In this article, I would like to discuss several such textual phenomena in Exodus and Deuteronomy.

Several textual ambiguities in Exodus 19-24 raise the question: Did the people hear the Ten Commandments directly from God or only through Moses, acting as an intermediary? Did the people hear certain words and commandments directly from heaven, or did they hear all of them through an intermediary human voice? To answer this question, I will examine four textual phenomena:

The first phenomenon is the meaning of the word qol (which can be translated as "sound," "voice," or "thunder"). This word appears seven times in the story of the revelation of the Torah in Exodus as an important Leitwort (leading word). The repetition of this word raises the question of its meaning in this context: thunder or voice? This question is especially relevant regarding Exodus 19:19: "Moses would speak, and God would answer him with a qol." In order to understand the meaning of the word qol in verse 19, we must examine a previous verse in the story, verse 16: "there was thunder [qolot], and lightning, and a dense cloud upon the mountain, and a very loud sound [qol] of the horn; and all the people who were in the camp trembled." There is no question that the meaning of the first qol in verse 16, next to the word "lightning," is "thunder." Because the word is used to mean thunder in a verse closely preceding it, the reader can be expected to attach this meaning to the word in verse 19 as well. Moreover, the references throughout the story to clouds and lightning reinforce this understanding. However, verse 19 itself mentions speech that elicits a response, and it could therefore be assumed that qol in this verse refers to a human voice, a speaking voice. The wider context of the chapter points the reader in one direction, while the immediate context of the verse leads in another. The narrator raises both possibilities but does not allow the reader to decide between them. This uncertainty is important because the understanding of the word has far-reaching theological implications about the 
nature of the revelation: Was revelation an overwhelming nonverbal event, or one that involved language? The first possibility leads us to one trend within Jewish thought that distinguishes between the concept of "command" (termed Gebot by Rosenzweig), which is of divine origin, and the details of the halakhah (Rosenzweig's Gesetz), which are not necessarily of divine origin.

The second possibility, that qol refers to speech, leads us to a different school of thought that holds that both the concept of command and the details of the commandments are of divine, not human, origin.

The second phenomenon is the ambiguous syntax found in the passage immediately following the Ten Commandments: "All the people saw the thunder and lightning, the sound of the horn and the mountain smoking. The people saw it and fell back and stood at a distance and said to Moses, 'You speak to us, so that we will hear; but let not God speak to us, lest we die"' (Exod. 20:15-16). ${ }^{7}$ When did this conversation take place? One might think: after God uttered the Ten Commandments, because the verses appear immediately after the conclusion of the last commandment. This, however, is a false impression. In biblical Hebrew, the vav ha-hipukh (vav consecutive) is used to express a sequence of events in which " $x$ " occurred, and afterwards " $y$ ", and then " $z$ ". However, the beginning of verse 15 does not use the vav consecutive (that is, it does not read "va-yar' kol ha'am"). Instead, it reads "ve-kol ha'am ro'im." This construction (vav+ noun+participle) is used in biblical Hebrew to describe an event that occurs at the same time as an event previously mentioned. ${ }^{8}$ In other words, it is how biblical Hebrew expresses a past perfect, or the idea conveyed in English with the adverb "meanwhile." If so, it is possible that this conversation between Moses and the people took place while God was uttering the Decalogue, in which case the people heard only some of the commandments directly from divine speech. It is also possible that this conversation took place before the declaration of the Decalogue, in which case the people did not hear any of the commandments. Moreover, Nachmanides points out that the people do not say "let not God speak to us, anymore" but merely "let not God speak to us." This wording would indicate that God had not yet spoken at all when the people asked Moses to act as intermediary! If so, all the laws - all of what Rosenzweig called the Gesetz-were given through an intermediary. What then is the relationship between the commandments in the Torah, God, and the people? Exodus raises this question but does not allow us to answer it decisively because the syntax and location of the verses in the narrative sequence can be read in multiple ways, enabling us to imagine several possibilities without imposing one definite answer. 
The third phenomenon is the relationship between the verb ro'im ("saw"; past form of "see") and its objects. One usually hears thunder but here, "All the people saw [ro'im $]$ the thunder and lightning, the blare of the horn and the mountain smoking" (20:15). Commentators have long debated whether this wording should be considered problematic or, even, paradoxical. Rabbi Akiva in the Mekhilta de-Rabbi Yishmael, ${ }^{9}$ Rashi, and, following him, Nahum Sarna argue that the wording is deliberately paradoxical in speaking of a visual apprehension of an aural phenomenon. On the other hand, Rabbi Ishmael (in the same section of the Mekhilta) claims that the verse means to say that the Israelites saw the visible, but heard the aural. In a similar vein, Moshe David Cassuto maintains that this is a zeugma, an expression that includes partial incompatibility; in this case, we have a transitive verb ("see") that is compatible with some of its objects (the lightning and the smoking mountain) and incompatible with others (the thunder and the blare of the horn). Ibn Ezra also rejected the idea of paradoxical wording and argued that the semantic range of the verb $r$-'- $h$ sometimes includes "perceive" in a general sense, not just "perceive through the eyes." In my opinion, even according to the opinion of Rabbi Ishmael and Cassuto, or Ibn Ezra, in this verse the least compatible object has been deliberately placed next to the verb in order to disturb the reader, and thereby to turn his attention to the nature of the revelation and the sensory experience involved in receiving the Torah. Was this a unique experience, inherently different from all other forms of communication? The wording of the verse is not necessarily paradoxical, but it is certainly problematic and liable to slow the readers down so that they can ponder how, precisely, the perceived matter came into the people's mind.

The fourth phenomenon is the absence of the indirect object in verse 20:1: "God spoke all these words, saying." ${ }^{10}$ This wording-namely, "God/ Hashem" coupled with "said/spoke" or "saying" — is very common in the Bible, appearing 339 times. In every other instance, the verse tells us who received the word of God. Here, the indirect object of his speech, prefaced by the preposition "to" ( $e l$, or the prefixed lamed) is conspicuously absent. It is extraordinary to find this ambiguity, of all places, in the story of the most crucial and significant revelation in history. God said something, but we do not know to whom he spoke. This verse raises the question: From whom did the People of Israel receive the exact wording of the Ten Commandments, from God or from Moses?

The book of Exodus, then, utilizes four phenomena of textual ambiguity to lead us to one crucial question: To what extent, and in what way, were the 
People of Israel connected to God at Sinai? We may rephrase this question several ways: Was there any direct contact between God and the People of Israel at Sinai? Did the people hear all Ten Commandments from the voice of God, or only some of them? Perhaps they did not hear the speech of God at all? Did God relate specific content directly to the people through the use of language, or was the revelation an experiential event, without verbal content? The number of such phenomena in one text indicates that the book of Exodus does not want us to know exactly what happened at Horeb. Quite the opposite-it wants us to wonder, to ponder, to discuss, and to ask questions, such as those asked by Rosenzweig and Heschel. If the People of Israel did not hear even one word from God, and the entire Torah was given to them exclusively through human mediation, they cannot know for certain if God actually said the words written in the Torah. It is possible that divine speech is not speech at all in the usual sense, as Maimonides argued. If so, Moses then needed to translate the supralinguistic message into human language.

\section{The Dawn of Jewish Exegesis: The Revelation of the Torah in the Book of Deuteronomy}

However, alongside these verses in Exodus, there are other voices in the Pentateuch that must be examined. I would like to discuss several aspects of the story of the revelation in Deuteronomy that respond to, and even challenge, the narrative in Exodus. The history of Jewish thought, by and large the history of arguments for the sake of heaven, begins when Deuteronomy confronts Exodus.

In Deuteronomy 4, Moses reminds the assembled people that "The day you stood before Hashem your God at Horeb ... Hashem spoke to you out of the fire; you heard the sound of words but perceived no shape-nothing but a voice" $(4: 10,12)$. These verses are interesting in light of the ambiguity that we saw in Exodus. According to Deuteronomy, the qol was qol devarim, "the sound of words" - that is to say: a voice, not just thunder. At Horeb, God uttered verbal content. The chapter continues with verse 13: "He declared to you the covenant that He commanded you to observe, the Ten Commandments." According to this verse, God addressed the people, not only Moses, when he uttered the Decalogue; "He declared to you." The second person plural form of the Hebrew word for "you" indicates that the people heard. This point is accentuated by the repetition of the second person plural in verses 11 and following (where each case in bold in the following is a plural form): "You came 
forward and stood ... Hashem spoke to you ... you heard . . . but saw no shape. ... related to you the covenant that He commanded you. ... For your own sake, be careful - for you saw no shape when Hashem your God spoke to you" (11-15). Deuteronomy appears to clarify the ambiguity on this matter found in the narrative in Exodus. Deuteronomy also challenges several verses in Exodus 19-24 that emphasize the visual aspect of the revelation at Sinai; Deuteronomy strongly insists that the people heard God but did not see Him (see verses 12 and 15).

All these motifs are accentuated in chapter 5: "Hashem our God formed a covenant with us at Horeb. It was not with our fathers that Hashem made this covenant, but with us, the living, every one of us who is here today. It was directly that Hashem spoke with you at the mountain from within the fire" (2-4). The repetition of the plural forms (in bold in the translation immediately preceding) clarifies, in contrast to the verses that we examined in Exodus, that God spoke to all of the people. The direct connection between God and the people is also indicated by the phrase "face to face." These verses emphasize the auditory contact between God and the people while God uttered the Ten Commandments. This motif appears also in the passage immediately following the Ten Commandments:

It was these words that Hashem spoke to your whole congregation on the mountain from within the fire, the cloud, and the fog-a great voice ( $q \circ l$ ), which did not continue.... When you all heard the voice ( $q \circ l)$ from within the darkness - and the mountain was on fire-that the leaders of your tribes and the elders drew near to me, and you said, "Look, Hashem has shown us His glory and His greatness; it was His voice ( $q o l)$ that we heard from the midst of the fire; today we saw that God can speak with a human, and the human lives. So now, why should we die? For this huge fire will devour us! If we continue to hear the voice ( $q o l)$ of Hashem our God any more, we will die! For who among all flesh has heard the voice of the living God speaking from the midst of the fire like us, and then lived? You go, and hear whatever Hashem our God may say; you can tell us all that Hashem our God tells you, and we will listen, and we will carry it out." (5:19-23).

These verses are a response to the ambiguities in Exodus 19 and 20. God spoke to all the people, not only to Moses. As we have seen, the syntax in Exodus 20 indicates that over the course of a dialogue that took place during the 
revelation of the Decalogue, or possibly even before God began to speak, it was decided that Moses would act as an intermediary. In contrast, when the author of Deuteronomy describes this dialogue, he uses the vav ha-hipukh in verse 20: "When (va-yehi) you all heard the voice." Therefore, Deuteronomy makes it clear that this dialogue took place after receiving the Ten Commandments; the people heard the entire passage and only afterwards approached Moses. Moreover, a comparison between the people's petition in each of the two books is revealing: Exodus 20:16 reads: "let not God speak to us, lest we die," whereas Deuteronomy 5:22 reads, "If we continue to hear the voice (qol) of Hashem our God any more, we shall die!"

Deuteronomy addresses each of the four ambiguities from Exodus that I pointed out earlier; in each case, Deuteronomy's purpose is to reject the possibility that the people did not receive the Ten Commandments directly from God. The revelation was public, not mediated; on this point Deuteronomy is both insistent and clear. Clear-yet equivocal. Deuteronomy 5:5 contradicts the verse that comes before it (as well 4:12-13 and 5:19-20). Immediately after the vivid description of the unmediated meeting of God and Israel in Deuteronomy 5:4, there follows a comment announcing that Moses acted as intercessor: "It was directly that Hashem spoke with you at the mountain from within the fire-I was standing between Hashem and all of you at that time, so as to tell you God's word, for you were afraid of the fire, and you did not go up the mountain-saying: 'I am Hashem your God'” (4-6).

The medieval commentators - Rashi, Rashbam, and Ibn Ezra-point out that the word lemor (saying) in verse 5 belongs to the sentence found in verse 4, since it completes the phrase in verse 4, which begins with the words "Hashem spoke." This renders the remainder of verse 5 parenthetical. We can go a step further than these commentators: Verse 5 (other than the word "saying") is a later addition to the text. It includes the formula "at that time," which (as Samuel Loewenstamm has demonstrated) consistently serves in Deuteronomy to indicate scribal interpolations. ${ }^{11}$ This interpolation reintroduces the idea of mediated revelation, which Deuteronomy specifically rejects.

While the unequivocal, straightforward narrative in Deuteronomy resolves the ambiguity in Exodus, this interpolation revives the possible reading originally rejected by Deuteronomy, destroys the continuity of the text, and turns the ambiguity of Exodus into a debate taking place within the final text of Deuteronomy. Because of this interpolation, the canonical text of Deuteronomy lacks the very clarity that its author had intended to achieve. 
This phenomenon is not unusual, and even illustrates a developmental pattern that appears repeatedly in later Jewish literature. The initial stage of this pattern is characterized by ambiguity or disagreement; in the second stage, an unequivocal, well-organized text resolves the previous ambiguity or disorder; the third stage is a reaction to that organized text and a return to the original positions. For example, the editors of the Mishnah created a well-structured and organized text to which the Gemara added complex argumentation and interpretation. In the Mishneh Torah, Maimonides attempted to compile complex and unstructured traditions into an accessible and well-organized framework. However, the work was accepted into the Jewish literary canon only after commentaries were appended to it that identified the contradictory opinions and reasoning that Maimonides had rejected! For example, in Hasagot haRavad, included in almost every edition of the Mishneh Torah, the commentator Rabbi Abraham ben David of Posquières (known as the Ravad) repeatedly disagrees with Maimonides and refers to the opinions that he did not include. It appears that Ravad's commentary was not the first critical commentary, or gloss, in Jewish literature. The original book to bear the title Mishneh Torah, the book of Deuteronomy, also received a critical commentary in the form of a later interpolation added by someone to whom we can dub "proto-Ravad" (Deut. 5:5).

This comparison between the two Mishneh Torahs is significant. I would even be so bold as to suggest that Deuteronomy is the first Jewish text, or, more specifically, the first text with rabbinic characteristics, not only because it explains or responds to earlier texts, but also because it has reached our hands with appended commentaries, comments, and critiques.

In these chapters, Deuteronomy expresses an opinion in another matter that is also a subject of controversy in the earlier books of the Torah. In Exodus 19-24 the revelation of the Torah is presented as an event, while in Leviticus and Numbers it is presented as a process. According to Exodus, God gave the Ten Commandments at Horeb and, almost immediately afterward, the laws in chapters 21-23. Moses then read out the laws to the people, and the people took it upon themselves to observe them. However, in Leviticus and Numbers the revelation of the Torah continues for years. At Sinai, God showed Moses the plan for the Tabernacle. After its construction, on the first day of the first month of the second year in the desert, God entered the Holy of Holies, and from there, on that very day, he first began to reveal the law to Moses, starting with the laws of sacrifices in Leviticus 1-7. 
However, the revelation of the Torah did not end there. After the ceremonies of the dedication of the Tabernacle, the revelation continued. From the conclusion of the ceremonies on the eighth day of the month until the end of that month, Moses received the laws in Leviticus 11-23. In the following month, in the Tent of Meeting at Sinai, Moses received additional laws (Num. $5: 6$ ), and on the twentieth day of the month the people left Sinai. Throughout the years of wandering in the desert and when they encamped in the steppes of Moab, Moses received additional laws that are found in other chapters in Numbers. From this it can be concluded that, according to Leviticus and Numbers, the revelation continued for many years. Moreover, certain stories in Leviticus and Numbers, such as that of the man gathering wood on the Sabbath (Num. 15:32-36) and the daughters of Zelophehad (Num. 27 and 36), convey the impression that the revelation is a process conducted through dialogue: Moses turns to God with halakhic questions and receives new laws or modifications of existing laws in response.

In this matter Deuteronomy agrees with Exodus, as can be seen clearly in verse 5:19: "It was these words that Hashem spoke to your whole congregation on the mountain from within the fire, the cloud, and the fog-a great voice, which did not continue [lo yasaf]." The Targumim, or standard rabbinic Aramaic translations, understand the last words of the verse very differently from my translation; for a Targum, the verse expresses the idea of continuous revelation: "a great voice that did not end." However, it is clear from other verses in which the verb yasaf is used that the meaning of this verse is that God's voice ceased and did not continue. Moreover, in contrast to Leviticus and Numbers, Deuteronomy does not include numerous instances of revelation of commandments and laws beginning with "Hashem spoke to Moses saying," and other similar formulas.

This debate over whether revelation was an event or a process did not end with the Bible. Profesor Yochanan Silman delineates various perceptions of the nature of the Torah in classical rabbinic literature and medieval Jewish thought. ${ }^{12} \mathrm{He}$ defines one perspective as the "Perfection Position," according to which the Torah that the People of Israel received was fundamentally whole and unchangeable. Thinkers and treatises adhering to this approach understand Deuteronomy 5:19 according to its simple meaning: the voice of God at Sinai "went on no more." However, according to the opinion that Silman describes as the "Being-Ever-Perfected Position," the revelation of the Torah to the Jewish people is a process that continues throughout the generations, in which the Torah itself develops and reaches a higher level of perfection. Thinkers and 
treatises adhering to this approach understand Deuteronomy 5:19 according to the Aramaic translations to mean that the voice of God on Sinai did not cease. They understand the word yasaf ("yod-samech-peh") as derived from the root $s-v-p$ meaning "end" (sof), thus indicating that the voice of God did not come to an end. A similar idea, that all the People of Israel, including generations not yet born, were present at Sinai and heard exactly what the generation of the Exodus heard, can be found in classical rabbinic literature. ${ }^{13}$ A similar opinion is reflected in the aggadah describing God's revelation to Moses of future rabbinic interpretations and questions. ${ }^{14}$ Rosenzweig and Heschel emphatically articulate this approach by arguing, in keeping with many Hasidic and kabbalistic sources, that the revelation of the Torah is happening now, whenever there is someone prepared to receive it. According to Heschel, in the third volume of his masterwork Heavenly Torah: As Refracted through the Generations, this opinion has important ramifications. Because all generations were present at Sinai, we can infer that the congregation of Israel in each generation has the right to hear through its own ears, to understand the divine imperative, and to translate it into practical halakhah. If so, it is possible that later authorities sometimes have the right to change the halakhah, to mold and to adapt certain commandments of human origin (Gesetz in Rosenzweig's terminology) so long as the authority of the divine command (Gebot) is not infringed.

On the one hand, Deuteronomy clearly belongs to the Perfection Position (in Silman's terminology) because it portrays the revelation as an event rather than a process. Moreover, Deuteronomy twice warns that it is forbidden to change its laws (4:2 and 13:1). Yet, surprisingly, in several places the book reveals an affinity to the developmental approach. At least in its current form, the passage informing us that the generation that stood at Horeb died in the wilderness (1:33-39) contradicts the verses that say that Moses' audience on the steppes of Moab witnessed the revelation at Horeb: "Hashem our God made a covenant with us at Horeb. It was not with our fathers that Hashem made this covenant, but with us, the living, every one of us who is here today" (5:2-3). The tension between these two passages is significant. Moses pointed out that the covenant he was describing happened at Horeb, because he was speaking in Moab forty years after the revelation and reminding his audience what had happened there. If he were still at Horeb, he would not have added this geographical detail. In truth, God made the covenant at Horeb with the parents of those whom Moses addressed in Moab in Deuteronomy 5. Deuteronomy mentions two covenants: one made at Horeb and the other a generation later in Moab. The verse that begins the narrative of the covenant in Moab acknowledges 
this: "These are the terms of the covenant which Hashem commanded Moses to conclude with the Israelites in the land of Moab, in addition to the covenant which He had made with them at Horeb" (Deut. 28:69). The words "in addition" challenge the book's portrayal of the revelation as a onetime event and present the formation of the covenant as a repeating occurrence. The people enter the covenant "today" in chapter 29, despite the fact that the covenant had already existed for forty years.

Similarly, we read: "You_-all of you-are standing here today in the presence of Hashem your God. . . . It is not only with you that I am making this covenant, with its sanctions, but with everyone who is here with us, standing in the presence of Hashem our God today, and with everyone who is not here with us today" (29:9, 13-14). Chapter 5 asserts that those who were born or grew up after the revelation were present at Horeb. Chapter 29 declares that those not present in Moab nevertheless also entered the covenant made there. We can conclude from these verses that the covenantal events both at Horeb and Moab were not limited to those specific points in time. It can be said that God made a covenant with those not yet born at the time of the revelation of the Torah; Moses' speech in Moab was directed also to those born generations after the speech was given. The events at Horeb and Moab were not onetime occurrences. In an important way, they continue so that those born later can participate in them. These passages therefore challenge the claim that the revelation was a onetime event, and bring Deuteronomy closer to the developmental approach.

The word "today" (ha-yom), which appears frequently in Deuteronomy, is very important in this context. It appears six times in chapter 4 and three times in chapter 5. In the remainder of the book the expression "that I command you this day" appears twenty-four times. This word, so strongly emphasized in Deuteronomy, has multiple meanings. It usually refers to the day of the speech in Moab, but a few times it means the day of the revelation at Horeb (Deut. 5:21). However, the repeated use of this Leitwort hints that the reference is actually to the day in which the book is being read. In other words, "today" could be any day, any given time, the today of whoever reads or chants Deuteronomy. If so, the voice on Horeb continues to be heard, and the Aramaic translators Onkelos and Yonatan were to a large extent correct when they translated "a great voice that did not end." The fundamental position of Deuteronomy is that the covenant is continual; God commands the people in every generation. We can conclude that the book is an important precedent for the Being-Ever-Perfected Position. There is also a profound affinity between Deuteronomy and the 
perspectives of Rosenzweig and Heschel inasmuch as they emphasize the timelessness of the divine imperative with references to verses from Deuteronomy that contain the word "today."

This duality in Deuteronomy - its adherence to both of the positions described by Silman - is also reflected in the verses that warn us not to change its laws. While in principle Deuteronomy opposed emending the law, in practice its author does not obey his own rule. It is well known that, according to the straightforward meaning of the text, Deuteronomy 12-26 contains numerous adaptations of the Book of the Covenant in Exodus 21-23. The very same book that admonishes its reader, "You shall not add anything to what I command you or take anything away from it" (Deut. 4:2), changed the status of the Hebrew maidservant mentioned in Exodus 21 so that she received the same rights that Exodus gave only to the male Hebrew slave. The very book that forbids innovation and expansion itself innovates and expands earlier laws in almost all its chapters. Though the book forbids us to add to its laws, these laws must be supplemented if they are to be observed. Like all biblical and ancient Near Eastern legal codes, the set of laws presented in Deuteronomy does not constitute a comprehensive legal system. Rather, it includes a representative sample of the legal practices of the People of Israel. ${ }^{15}$ Without additions from the tradition from which the book was derived, it is simply impossible to implement its laws. One wonders, therefore, to what extent the author of Deuteronomy expected us to take at face value the prohibition of adding to or subtracting from the laws.

\section{The Centrality of Obligation}

According to the concept of revelation propounded by Rosenzweig and Heschel, the Torah, in the sense of law and commandment, is a response to divine revelation. In other words, the People of Israel wrote the Torah in response to divine instruction. Is a response that does not express itself in legal form also legitimate? According to Martin Buber, revelation entails the creation, not of halakhah, but of a connection between man and God. ${ }^{16}$ Revelation can be interpreted as theology or emotional fervor, and not necessarily as law.

For the first three thousand years, until the nineteenth century, the quintessential and universal Jewish response to revelation was the formulation of laws and obedience to them. The consistency of this response indicates that, at Sinai, the Jewish people perceived God specifically as an entity who issued a command. The fact that the Jewish people interpreted the divine imperative 
as law indicates that revelation was not limited to God's appearance and the establishment of a connection with him, but also included the demand for halakhic obedience, although it was left to the people to formulate the halakhah. According to Rosenzweig, God gave a general command, and the details of the halakhah were created by the Jewish people. At the revelation at Sinai, God declared "I command you to ..."; throughout the generations the People of Israel have been completing that sentence. While the Jewish people fill in the object of the verb, God remains its subject and the verb never loses it basic meaning of demanding obedience.

The sources within the Torah itself make it clear that Israel's response to the event at Sinai has always been expressed in the form of commitment. In all the sources, we find laws that are justified by means of a story. ${ }^{17}$ All the sources concur about the nature of the Torah, and all agree with the first commentary of Rashi to Genesis - that the Torah is a combination of legislation and narrative. Specifically, the Torah is comprised of laws that derive their justification from the narrative context in which they appear. The sources disagree on the important questions such as how, when, and where revelation occurred, and, above all, which laws specifically have to be obeyed. However, all agree unanimously that the People of Israel's response to the event of revelation must be legal or halakhic.

In the Pentateuch itself, the meaning of revelation is the giving of the law (mattan torah). This is true not only of the Pentateuch as it appears now, but also of all the sources that modern research identifies as comprising the Torah. The concept of revelation as the giving of the Torah or divine imperative is thus older than the Pentateuch itself, and is accepted by groups as disparate as the Karaites, Saducees, the Qumran cult, the Samaritans, and, of course, the sages. The antinomian approach cannot look for substantiation or support either in biblical criticism or the sources that it has revealed. J, E, P, and D-all affirm the centrality of the halakhah.

\section{The Bible: Written Torah or Oral Law?}

I must acknowledge that my argument has a far-reaching implication: the entire Bible, from the first words "In the beginning God created," is oral law. The Bible itself, including the Ten Commandments, is comprised of human language that develops and interprets the divine command. In my opinion, this characterization of the Bible as oral law is a necessary corollary of Rosenzweig 
and Heschel's approach, although they did not explicitly say as much in their writings, and might very well have recoiled from it.

On its face, this is a radical and problematic argument. However, on closer examination it becomes clear that, on a practical level, it does not conflict with halakhic observance or belief in the sanctity of the Torah. Texts that are clearly regarded as the Oral Law are comprised of both human and divine elements. For example, traditional belief holds that the text of the Mishnah was composed by Rabbi Judah the Prince and his colleagues, but that its content is from Sinai. In this case, it is difficult to draw the line between human content and divine imperative. Although this lack of clarity is present from the incipient stages of the Oral Law, it is not perceived as a challenge to its authority, or as problematic in any way. I would like to argue that the same is true regarding the Written Torah. For example, I know that the details of the laws of tefillin originate in the Oral Law and were formulated by human beings. This knowledge does not prevent me from putting on tefillin every morning out of a sense of obligation to fulfill a divine command, even though the details of the commandment are the inventions of human sages. I believe that the verses in Exodus and Deuteronomy that were the basis for this specific halakhah were written by human beings. This belief, however, does not prevent me from observing the commandant according to the halakhah. I believe that the verses in the Torah, like the specifics of the halakhah in the Mishnah, the Talmud, and the legal codes and responsa, are all human responses to divine command.

Moreover, my claim that the Bible, in a certain sense, can be regarded as oral law is less audacious than appears at first glance. Already in classical rabbinic literature there is a tendency to blur the border between the two "Torahs" written and oral-or to eliminate it entirely. ${ }^{18}$ Here I will limit myself to three examples. The first example is from the midrash: "The words of Torah are all one and they include Bible, Mishnah, halakhah, and aggadah."19 The second example is from the Babylonian Talmud:

Rabbi Levi bar Hama said in the name of Reish Lakish: It is written, "and I will give you the stone tablets, and the Torah, and the commandments which I have written, to teach them" (Exod. 24:12) — "Stone tablets" these are the Ten Commandments; "Torah" - this is the Bible ${ }^{20}$; "commandments" - this is the Mishnah; "which I have written" - these are the books of the Prophets and Writings; "to teach them" - this is the Gemara. This teaches us that all were given to Moses at Sinai. ${ }^{21}$ 
In this aggadah the components of the Oral and Written Torahs are mixed together. The order is not, as we would expect, "Pentateuch, Prophets and Writings, Mishnah, and Gemara." Instead, it is "Pentateuch, Mishnah, Prophets and Writings, Gemara." All of them are Torah, without any differentiation between the Oral and Written Torahs. The order might even lead us to conclude that the Mishnah is more important than the Prophets and Writings, as some traditional commentators have argued. ${ }^{22}$

The final example is from a midrash:

When God appeared at Sinai to give the Torah to Israel, he presented it to Moses in the correct order: Bible, Mishnah, Talmud, and aggadah, as it is said, "God spoke all these words, saying" (Exod. 20:1). Every question that a student asks his teacher was revealed to Moses at that time. After God taught Moses the Torah, He asked him to teach it to the People of Israel. Moses said to him, "Master of the World, I will write it down for them." God said to him, "I do not want you to write it down for them, because I know that in the future idol worshippers will rule over them and will take it from them. Rather, I will give them the Bible in writing, and the Mishnah, Talmud, and aggadah I will give orally. This way, even when they are subjugated to the idolaters, they will remain distinct from them." 23

According to this midrash, the entire Torah was originally oral, and there is no substantive difference between the material that ended up in the Written Torah and the material that remained oral. For practical reasons God decided to turn some of the material into the Written Torah. The default position, God's first choice, the original form of the Written Torah, was oral. Here the borders between the Written and Oral Law are not blurred; they are erased.

\section{Practical Implications}

There are two practical ramifications of this position. The first is that a Jew who understands the revelation of the Torah, as I have described it here, will continue to observe the commandments, but without complete certainty that all his or her actions reflect the will of God. If the Torah in our possession is a human translation of the divine command that we all heard at Sinai, we must recognize that no translation is perfect. A human translation of the divine may 
be especially prone to contain some errors. Therefore, when we observe the commandments we should act with humility rather than exaggerated selfconfidence. This is a danger inherent to all religions: a person who is confident that he or she understands exactly what God wants will lack the humility befitting a religious person. Alas, empirical evidence abounds demonstrating the correlation between certainty regarding God's will, on the one hand, and arrogance, inflexibility, and intolerance, on the other. Moreover, people who understand that they are reading a translation of the divine will should constantly doubt their own behavior. This doubt, rather than impairing religious practice, enriches and deepens it.

The second ramification is that if the particulars of the halakhah are of human origin, specifically of Jewish communal origin, the possibility exists that, under certain conditions, Jewish communities can participate in the ongoing process of creating the Oral Law; that is, they can change the halakhah. The important and difficult questions of how, when, and under whose authority such changes can be made are outside the scope of this article. Others with greater expertise in Jewish law can address them. I will limit myself to two comments. First, God gave the Torah to the Jewish people. If the Jewish people are the "owners" of the halakhah, they have the right to change it. Second, not all Jewish communities have the right to change the halakhah. God gave the Torah to the whole Jewish nation, but not all Jews accepted it. "Ownership" of the Torah as well as the right to contribute to its development by amending it belongs only to those communities that received the Torah-in other words, those who are committed to observing it and demonstrate this commitment on a daily basis.

In light of my position that the Written Torah is an early form or example of the Oral Law, and that the Oral Law is a continuing developmental process, it can be asked: Can we conceive of the possibility of changing the text of the Written Torah? Can we eliminate verses from the Torah, such as those commanding genocide, on a moral basis? Can we rewrite the text of the Bible from a feminist perspective? The answer is no. The idea that the Oral Law is capable of development and expansion does not mean that existing texts should be rewritten. The amoraim did not rewrite the Mishnah but added to it. (The fact that scholars of the text of the Mishnah can point to occasional exceptions to this rule does not invalid my basic argument). The Rishonim did not rewrite the Talmud; they wrote new works intended to complete, not replace it. In our day, it is neither possible nor desirable to change existing texts. It is both possible and desirable, however, to add 
additional volumes to the corpus of Torah that interpret earlier works, respond to them, and complete them. It is my hope that these new works will help the Jews of today and future generations to come closer to the God who commands us to "expand Torah and glorify it" (Isa. 42:21).

\section{Endnotes}

1. This article outlines a specific way of understanding the revelation of the Torah. Detailed exegetical explanations, references to further primary and secondary sources, and responses to potential criticism can be found in my book Revelation and Authority: Sinai in Jewish Scripture and Tradition (New Haven: Yale University Press, 2015).

2. I have borrowed this expression from Maimonides' eighth principle of faith in his introduction to the commentary to perek Helek of Mishnah tractate Sanhedrin. It is important to remember that immediately before these words, Maimonides warns that the expression "like a scribe taking dictation" is a metaphor, and that in fact no one really knows how Moses received the Torah. Both in The Guide of the Perplexed and in this passage, Maimonides clarifies that the "divine" speech at Horeb was not really speech at all.

3. Franz Rosenzweig, On Jewish Learning, ed. Nahum Glatzer (New York: Schocken Books, 1965), 118. Rosenzweig quotes Exod. 19:23 and 20:1.

4. Abraham Joshua Heschel, God in Search of Man: A Philosophy of Judaism (New York: Farrar, Straus and Giroux, 1955), 185, 274. Heschel quotes from Tanna de-Vei Eliyyahu Zuta 2:1.

5. On Rosenzweig as an advocate of the view that the halakhah is obligatory and authoritative, see Isaac Heinemann, Ta'amei ha-Mitzvot be-Sifrut Hiazal [The reasons for the commandments in Jewish thought] (Jerusalem: Horev, 1993), 2:195-237; Revelation and Authority, $128-135$.

6. A study of the discussion of these questions in classical and medieval rabbinic literature and their implications can be found in Abraham Joshua Heschel, Heavenly Torah: As Refracted through the Generations, ed. and trans. Gordon Tucker (New York: Continuum, 2006); and Yochanan Silman, Kol Gadol ve-lo Yasaf: Torat Yisrael bein Shlemut le-Hishtalmut [The voice heard at Sinai] (Jerusalem: Magnes, 1999).

7. Verses 18-19 in other editions of the Bible. On differences in the division into verses see Mordecai Breuer, "Dividing the Decalogue into Verses and Commandments," in The Ten Commandments in History and Tradition, ed. Ben-Zion Segal; English version ed. Gershon Levi (Jerusalem: Magnes, 1990), 291-330.

8. See Gotthelf Bergsträsser, Dikduk ha-Lashon ha-Ivrit [Hebrew grammar], trans. Mordechai Ben-Asher (Jerusalem: Magnes, 1982), 428-429 (pt. 2, sec. 13, d-e); and Jan Joosten, The Verbal System of Biblical Hebrew (Jerusalem: Simor, 2012), 125-130.

9. Parashat Debehodesh, 9 .

10. This phenomenon was first pointed out by Aryeh Toeg, Matan Torah Be-Sinai [Lawgiving at Sinai] (Jerusalem: Magnes, 1977).

11. Samuel Loewenstamm, "Ha Nusha 'ba-Et ha-Hi' be-Ne'umei ha-Petiha shel Sefer Devarim" [The wording of the phrase "at this time" in the introductory speeches of Deuteronomy], Tarbiz 38 (1969): 99-104.

12. Kol Gadol ve-lo Yasaf.

13. Midrash Tanhuma, Nitsavim; Babylonian Talmud, tractate Shavuot 39a, tractate Shabbat 146a. 
14. Jerusalem Talmud, tractate Pe'ah 13a; several instances in Midrash Rabbah.

15. On this point see Samson Raphael Hirsch, who understood on a profound level the nature of the Written Torah as it contrasts to the Oral Law. On this aspect of Hirsch's work, see the discussions by Alan Levenson, The Making of the Modern Jewish Bible: How Scholars in Germany, Israel and America Transformed an Ancient Text (Lanham, MD: Rowman and Littlefield, 2011), 50; Jay Harris, How Do We Know This? Midrash and the Fragmentation of Modern Judaism (Albany: SUNY Press, 1995), 226-227.

16. For Buber's approach to halakhah and its connection to revelation, see in particular his correspondence with Rosenzweig in On Jewish Learning, 72-92.

17. I am referring to the four textual sources, J, E, P, and D, identified by biblical critics.

18. See the many examples provided in Revelation and Authority, chap. 4.

19. Sifrei Devarim, Ha'azinu.

20. Rashi comments here that this is the Pentateuch, because there is a commandment to read the Torah.

21. Babylonian Talmud, tractate Berakhot 5a.

22. See, e.g., Ein Ya'akov and its commentaries on this passage, Ahavat Eitan and Iyyun Yaakov.

23. Shemot Rabbah 47:1 (and parallel texts). 